\title{
Editorial
}

\section{Social responsibility of medical journal: a concern for COVID-19 pandemic}

Agus Rizal Ardy Hariandy Hamid

Check for updates

"A medical journal has a social responsibility to improve the human condition and safeguard the integrity of sciences." World Association of Medical Editor (WAME)

Social responsibility can be defined as an ethical framework for contribution in community welfare. The Universal Declaration on Bioethics and Human Rights, especially on the Article 14 , has explained the issue of social responsibility and health. ${ }^{1}$ However this statement only focused on the government's obligation to execute this. Thus, The United Nations Educational, Scientific and Cultural Organization (UNESCO) published "Report of the International Bioethics Committee of UNESCO (IBC) on social responsibility and Health" in 2010 which adopted and expanded this statement. "All sectors of society" should participate in the health promotion and social development as a social responsibility. ${ }^{2}$ Hence, a medical journal should be considered as a part of the society which also has a social responsibility. Lundberg has explained many social responsibilities in medical journal editing. ${ }^{3}$ World Association of Medical Editor emphasized at least two social responsibilities of medical journal editors. Besides publishing the high-quality articles, the medical journal editors should consider the improvement of the human condition and safeguard the integrity of sciences to maintain ethical issues for benefit of the community. ${ }^{4}$

As a social responsibility to publish a highquality peer-reviewed article, the Medical Journal of Indonesia (MJI) has improved the editorial process of the submitted manuscript. There should be an ethical clearance or informed consent in each responding manuscript to maintain a safeguard of the integrity of the article. The peer-review process has been improved to accommodate the editorial rejection decisions, executed in any step during the process. Strict requirements after initial screening has also been implemented and failure to fulfill these in a specified time will result in a rejection of the manuscript. Checklists from the Equator Network ${ }^{6}$ are used as a reference to set up a minimal requirement of the manuscript's content. The MJI has implemented a time limit in each step of peer-review process to help all editorial team to be more focus in guarding a good peer-review process and find a fast solution for a problem that arises in each step. Moreover, to improve the articles' record, the MJI also implemented CrossMark button to help readers in knowing the update of the published articles start from this issue and in all previously published articles that have any updates. Meanwhile, the published articles will not be changed for the update.

Related to the responsibility to the community, the $\mathrm{MJI}$ believes it is necessary to involve more in an essential health issue as a part of social responsibility. Besides publishing regular articles, the Editorial Team of $\mathrm{MJI}$ has decided to publish a dedicated topic related to essential health issues in Indonesia or worldwide. This initiation has been started in 2017 when the MJI published an invited editorial which explained about the health promotion in Indonesia from Ministry of Health Republic of Indonesia. ${ }^{5}$ The Editorial Team of MJI decided to select and call for papers on a dedicated topic in each issue. All these manuscripts follow a standard peer-review process and may also be declined. The accepted article should accomplish the revision with a strict schedule to be published in a specific publication schedule. Furthermore, the MJI has also added a new section which termed "Commentary". This section includes invited articles from the expert, professional society, or the government to give an opinion for the dedicated topic. In this issue, the topic is air pollution. Indonesia has almost a regular wildfire incidence each year in some areas which considered as source of health problems in rural or urban areas. We requested a representative of Ministry of Environment and Forestry Republic of Indonesia and Indonesian Society of Respirology to give opinion about air pollution. 
Recently, we concerns about coronavirus disease 2019 (COVID-19) in Indonesia and worldwide. As mentioned in other editorial of this issue, the cases have rapidly increased in a very short period of time. Being the fourth largest populated country in the world, Indonesia bring a risk for large number of infection and high viral spreading. Furthermore, this virus is very contagious which needs to be prevented for spreading in the community. As World Health Organization (WHO) declared this COVID-19 as a pandemic condition, the focus should be on more rapid and earlier detection to halt the number of the infection and to implement proper management in limiting viral transmission. The uncontrolled transmission leads to huge number of cases and overwhelm the healthcare capacity system. Consequently, the number of mortality cases will tremendously increase as we have seen in some countries. On March 18, 2020, Italy reported the highest daily death cases (>400). The increasing number of mortality cases in Indonesia should be an alarmed sign for the government.

The healthcare capacity depends on the health workers and logistic availability. Both medical and non-medical logistics should support the high level of personal protective equipment due to this very contagious virus. The guarantee of the logistic availability should be considered by the government. This condition can be a hurdle in Indonesia because many of these still depends on imported logistic. This is the right time to consider about a national capacity to produce high quality health equipment. Meanwhile, the government should find other alternatives to get this imported logistics. Health workers are the highest risk to be infected especially when dealing with patients with no symptoms. The infected health workers lead to reduce number of health workers who actively treat the patients. Report from Italy showed about $8 \%$ of mortality cases were health workers. Thus, the MJI advocated the government to make a meticulous grand plan to overcome this outbreak and the social impact of it in Indonesia.

Many scientific journals have involved to publish a fast peer-reviewed article related to COVID-19. This fast publication aims to achieve fast credible knowledge dissemination worldwide, so all of the scientists can learn each other on how to overcome this pandemic as soon as possible. Many medical societies have also published specific recommendations which are needed to directly deals with this outbreak. Thus, the MJI decided to involve in this knowledge dissemination by doing a fast track publication related to COVID-19 as one of the social responsibilities. The MJI are going to carry out this COVID-19 related fast track publication throughout the year, beside the dedicated topics as explained before. We hope this can increase the knowledge of this outbreak.

The Indonesian government has implemented many public recommendations to contain COVID-19 transmission. ${ }^{7}$ The participations from the community are a vital role to overcome this pandemic condition. Many countries have shown the obedience of the community to the government's decision has influenced the growing cases and death cases. The community should implement the social distancing and self-isolation protocol since there are also some asymptomatic COVID-19 patients who are called as carriers. The personal hygiene behavior, including handwash, should be implemented regularly, as soon as we have touched anything. We realize that there are many obstacles for this implementation in Indonesia due to the economic and religious reasons. The MJI expects that all of Indonesian people consider on how this infection spreads and how it affects our body, including death, so we believe that the people are willing to limit the transmission in certain and special ways according to WHO recommendations. Furthermore, there is an Indonesian culture called "gotong royong" which means we help each other in every situation. This culture should be the light spark for the whole world, that we, Indonesia, can face this pandemic together as one nation. On the other hand, we need a strong leadership to orchestrate all Indonesian elements to handle this condition together and efficiently.

"A nice orchestra music can only be achieved by a strong and harmonious leadership of the conductor"

(Rizal, 2020)

From Medical Journal of Indonesia pISSN: 0853-1773 • elSSN: 2252-8083 https://doi.org/10.13181/mji.ed.204629 Med J Indones. 2020;29:1-3

\section{Corresponding author:}

Agus Rizal Ardy Hariandy Hamid

E-mail: rizalhamid.urology@gmail.com

\section{REFERENCES}

1. United Nations Educational, Scientific and Cultural Organization (UNESCO). Universal declaration on bioethics and human 
rights. Paris; 2006.

2. United Nations Educational, Scientific and Cultura Organization (UNESCO). Report of the International Bioethics Committee of UNESCO (IBC) on social responsibility and health. France: Social and Human Sciences Sector, Division of Ethics of Science; 2010.

3. Lundberg GD. The social responsibility of medical journal editing. J Gen Intern Med. 1987;2(6):415-9.

4. World Associations of Medical Editors (WAME). About us [Internet]. 2016 [cited 2020 Feb 28]. Available from: https:// wame.org/aboutus.
5. Moeloek NF. Indonesia national health policy in the transition of disease burden and health insurance coverage. Med J Indones. 2017;26(1):3-6.

6. The EQUATOR Network. Enhancing the quality and transparency of health research [Internet]. [cited 2020 Feb 28]. Available from: https://www.equator-network.org.

7. Menteri Kesehatan Republik Indonesia (Jakarta, Indonesia). Letter to Pimpinan Kementerian/Lembaga; Gubernur; Bupati/ Walikota Seluruh Indonesia (Indonesia). 2020 Mar 16. 4 leaf. Protokol isolasi diri sendiri dalam penanganan coronavirus disease (covid-19). No.:HK.02.01/MENKES/202/2020.

\section{Visit to Singapore Medical Journal during COVID-19 outbreak: learning "beyond" the expectation}

Felix Firyanto Widjaja, Windu Cahyaningrum Handayani Notonagoro Suryaningrat

In the end of January 2020, some members of the Editorial Team of Medical Journal of Indonesia (MJI) visited Singapore Medical Journal (SMJ). With the support from Prof. Wilfred CG Peh who is the Editorial Board Member of MJI and Past Editor-in-chief of SMJ, it is an honor to get approval from Prof. Poh Kian Keong as the current Editor-in-chief of SMJ for the visit. The SMJ has been published by the Singapore Medical Association since 1960, earlier than the MJI. The journal has also been indexed in well-known indexing databases, such as Index Medicus (PubMed) and Web of Science (Clarivate Analytics) with impact factor of 1.141 in $2018,{ }^{1}$ which means there was an average of 1.14 citations in 2018 from each published article during the period 2016-2017..$^{2}$ Moreover, the SMJ and the MJI share similar aim and scope in general medicine.
We learned much about journal management and manuscript handling from the four SMJ's editorial staff; and will adapt some adjustments for the MJI's improvements. Most of the journal in Indonesia was run as a "small medical journal", of which the editorial team needs to take part both as editor and publisher. As the editor, the editorial team has to guarantee the timely, accurate, and fair peer-review process; and ensure the availability of high-rate articles. In the meantime, as the publisher, the editorial team needs to ensure a user-friendly system for handling the manuscripts, ensuring high-quality print and electronic versions that are economically feasible, and finding potential revenue by advertising. ${ }^{3}$ The editorial team needs to overcome all the works while remaining committed to the publication ethics.

Figure 1. Total confirmed and tested cases of COVID-19 in Indonesia since March 1, 2020 (data from https:// infeksiemerging.kemkes. go.id)

*adjusted based on new criteria of suspected cases and contacts with confirmed case

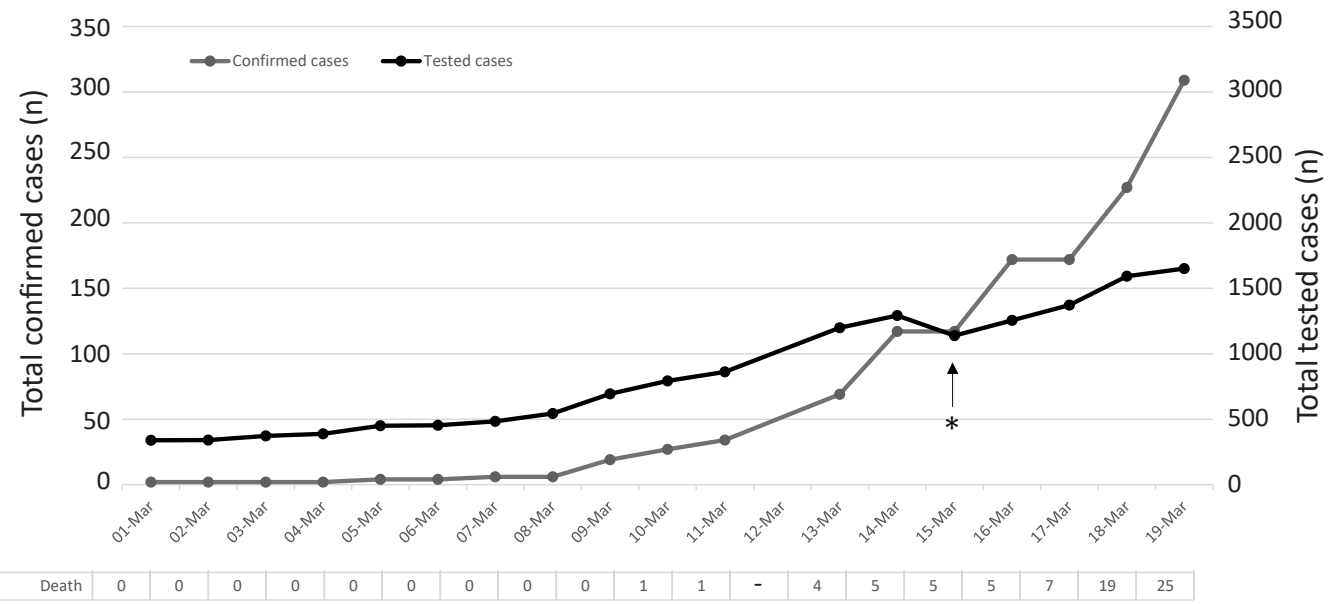

Copyright @ 2020 Authors. This is an open access article distributed under the terms of the Creative Commons Attribution-NonCommercial 4.0 International License (http:// creativecommons.org/licenses/by-nc/4.0/), which permits unrestricted non-commercial use, distribution, and reproduction in any medium, provided the original author and source are properly cited. For commercial use of this work, please see our terms at https://mji.ui.ac.id/journal/index.php/mji/copyright. 